\title{
Heavy metal contamination in surface water of Mohammedia wetland, Morocco
}

\author{
Halima Jounaid ${ }^{1,}{ }^{*}$, El Mehdi El Hachimi ${ }^{1}$, Nihad Chakri $^{1}$, Toufik Remmal $^{1}$, Btissam Elamrani ${ }^{1}$, and Fouad Amraoui ${ }^{1}$ \\ ${ }^{1}$ Hassan II University of Casablanca, Faculty of Sciences Ain Chock, Department of Geology. Km 8 Route d'El Jadida, Casablanca \\ 20150, Morocco.
}

\begin{abstract}
Assessing heavy metal concentrations in wetlands and identifying sources of metal contamination are critical steps in protecting wetlands. Using seven sampling stations, we evaluated the spatial variation of some heavy metal concentrations in surface waters of the Mohammedia wetland and a selected segment of the El Maleh wadi that feeds the wetland. Field observations made it possible to identify and map the pollution discharged into El Maleh wadi, carrying heavy metals into the wetland. The analyses showed that the concentrations of lead, manganese, and cadmium far exceed the thresholds relating to fish life in $100 \%$ of sampling stations. All the evidence points to heavy metals contamination of surface water in Mohammedia wetland, generated by industrial activities, wastewater discharges, and leachate from the old landfill located upstream.
\end{abstract}

\section{Introduction}

Water quality is a potential factor in supporting biodiversity [1]. Water quality degradation can seriously affect wetland ecological functions [2-4]. Heavy metals from anthropogenic sources are considered one of the most common types of pollutants [5]. Heavy metals are widely present in rivers and serve as important indicators of environmental water quality [6]. Riverine input and runoff from land carry pollutants into estuaries, thus impacting biotic communities and sensitive habitat areas [7].

Mohammedia wetland, located in the eponymous city in the west of Morocco, is a Ramsar site corresponding to El Maleh Wadi's estuary and its flood plain [8]. The wetland mainly consists of some marshes fed by rainfall and El Maleh Wadi floods, a permanent water body supplied by seawater during high tide, and another permanent body of water fed by groundwater [9]. In the latest decades, the urban development of Mohammedia city has led to the release of wastewater into El Maleh Wadi. Several industries (mainly an oil refinery and coal-fired power plant) surrounding the wetland also pose a severe threat. Some studies are available on the surface water quality of Mohammedia wetland [10-11] but have not assessed heavy metals in surface water.

In this paper, we highlight the spatial variation of some heavy metals in mohammedia wetland surface water. The goal is to investigate heavy metal concentrations in different areas and identify heavy metals contamination sources of Mohammedia wetland as the first step for its protection and Restauration. Physico-chemical analyses were carried out on five heavy metals. The concentrations obtained for each parameter are compared to the thresholds tolerable for fish life [12]. The objective is to verify the ability of Mohammedia wetland to offer natural conditions for biodiversity.

\section{Materials and Methods}

The sampling network was designed to cover sites that reasonably represented El Maleh Wadi's water quality, taking into account discharges identified during the field observations and impacting Mohammedia wetland water quality. Sampling station 11 is chosen as the reference station given its location far from anthropogenic disturbances. The surface water samples were made in June 2019. All samples were collected in double, in new polypropylene bottles rinsed with deionized water, then stored at $4{ }^{\circ} \mathrm{C}$ in the dark and transported on the same day to the laboratory. The analyses were performed according to Rodier [13] in the Laboratory "Geosciences Applied to the Engineering of the Development" (GAIA) in Hassan II University of Casablanca - Ain Chock Faculty of Sciences. Lead ( $\mathrm{Pb})$, Manganese (Mn), cadmium (Cd), Chromium (Cr), Zinc $(\mathrm{Zn})$, and copper $(\mathrm{Cu})$ were measured at seven selected points $(1-3,5,6,9-11)$ (Fig. 1).

\footnotetext{
* Corresponding author: jounaidhalima@gmail.com
} 


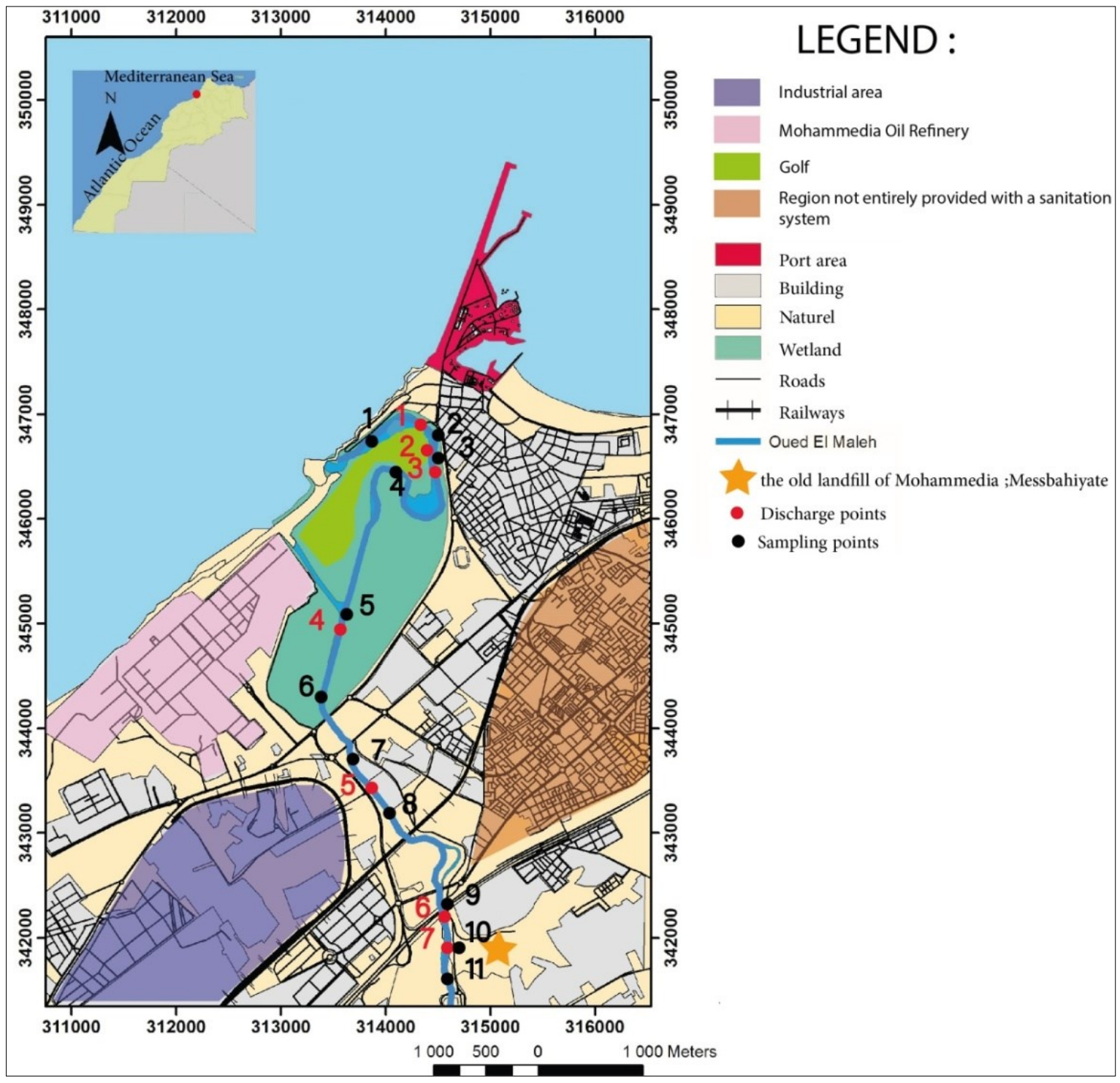

Fig.1. Study area and water quality sampling sites.

\section{Results and Discussion}

The mean concentrations of heavy metals are summarized in table 1. The Analyses carried out show that, apart from $\mathrm{Zn}$, all other heavy metals were detected in levels exceeding maximum values tolerable for fish life. The concentrations of lead in the study area are significant. Due to urban processes, $\mathrm{Pb}$ and other metals are regularly discharged into fields, water, and soils through sewage sludge, urban runoff, automobile exhaust, and gasoline containing $\mathrm{Pb}$ [14-15].

The highest concentration of lead recorded in the sampling station (S10) (Fig. 2a) may originate from the old landfill of Mohammedia city. During the field observations, we noted in this area leachate seepage into El Maleh wadi. Analyses carried out on the leachate from Mohammedia landfill have shown lead concentrations up to $690 \mu \mathrm{g} / \mathrm{L}$ [16]. Sample station ten also shows the highest concentration of manganese (Fig. 2b). Wastewater and industrial pollution are also responsible for surface water contamination by manganese [17]. Indeed, S9, S5, located near wastewater discharges in El Maleh wadi, show significant these parameters concentrations. Concerning cadmium, all levels detected far exceed the maximum allowable for fish life (Fig. 2c). Except in station 10, downstream concentrations are more important than those recorded upstream. Station S1, located in the estuary, shows the highest value $(100.5 \mu \mathrm{g} / \mathrm{L})$. The affinity of $\mathrm{Cd}$ can explain this with chlorine in a salty environment. This affinity results in the desorption of $\mathrm{Cd}$ from the particulates towards the dissolved phase [18-20]. The significant contamination of sites S1 and $\mathrm{S} 3$ by Cd could be related to phosphate fertilizers runoff [21] which could be used in the Mohammedia golf that covers 27 ha in this area. According to N'Gessman [21], some phosphate fertilizers have cadmium concentrations that can be about 300 times higher than the natural content of soils. Copper was detected in only three samples. The station (S10), located downstream from the landfill, records a value far exceeding the threshold of this parameter (Fig 2d), attesting to possible contamination of surface water by the leachate. 
Table 1. Parameters measured in the study area during June 2019

\begin{tabular}{|c|c|c|c|c|c|c|c|c|}
\hline Sampling station & S1 & S3 & S5 & S6 & S9 & S10 & S11 & Thresholds Fish life [12] \\
\hline $\mathrm{Pb} \mu \mathrm{g} / \mathrm{l}$ & 32.5 & 161.5 & 64.5 & 0.1 & 64.5 & 226 & 53.94 & 20 \\
\hline $\mathrm{Mn} \mathrm{mg/l}$ & 0.89 & 0.92 & 1.02 & 1.01 & 0.96 & 1.40 & 0.10 & 0.1 \\
\hline $\mathrm{Cd} \mu \mathrm{g} / \mathrm{l}$ & 100.5 & 78 & 60 & 48.5 & 53 & 77.5 & 47.5 & 5 \\
\hline $\mathrm{Zn} \mathrm{mg/l}$ & 0.27 & 0.23 & 0.022 & 0.07 & 0.04 & 0.32 & 0.15 & 1.3 \\
\hline $\mathrm{Cu} \mu \mathrm{g} / \mathrm{l}$ & - & 13.5 & - & - & - & 137 & 13 & 40 \\
\hline
\end{tabular}

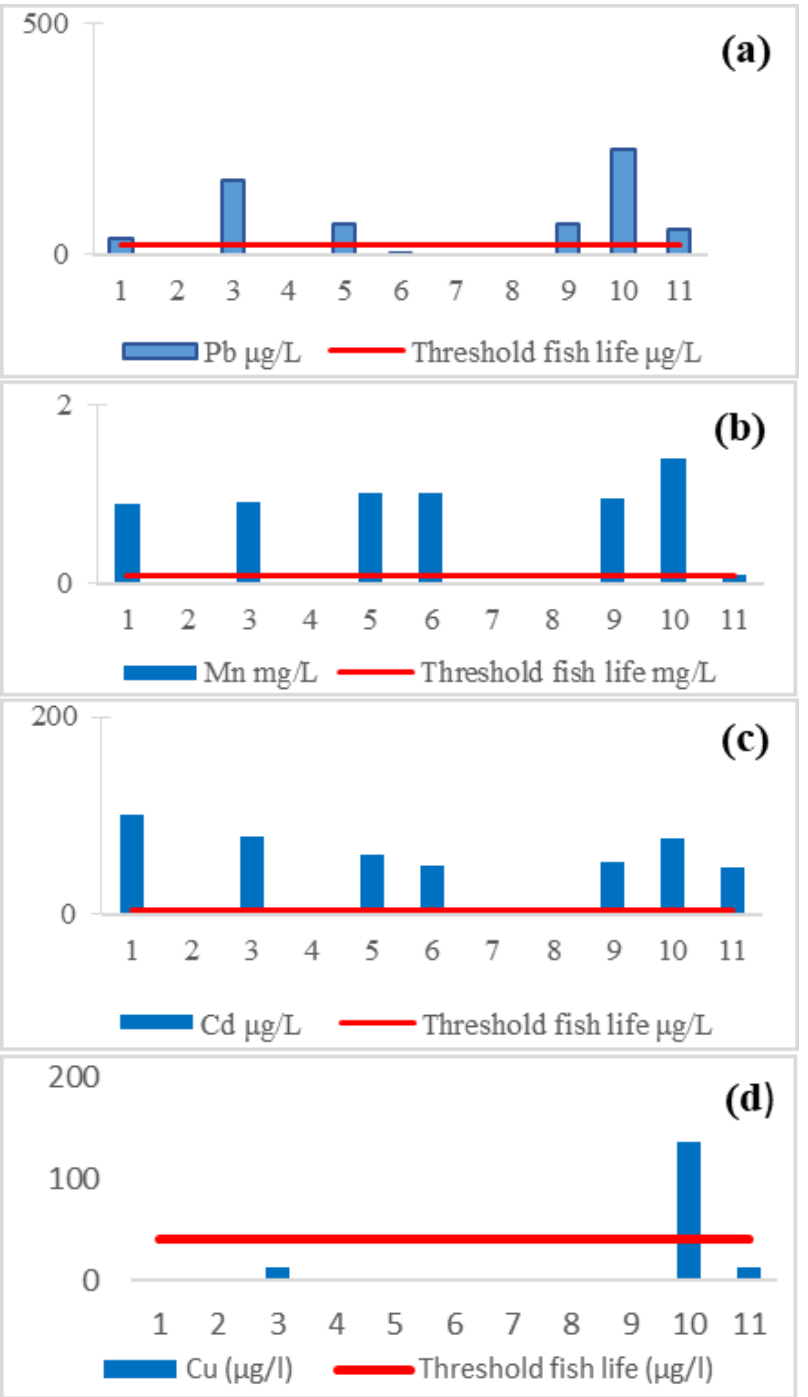

Fig.2. Spatial distribution of lead (a), manganese (b), cadmium (c) and copper (d) in the study area during June 2019.

\section{Conclusion}

In this study, industrial discharges, domestic sewage, and the old landfill of Mohammedia city were identified as potential pollution sources in the study area. $\mathrm{Mn}, \mathrm{Cd}$, and $\mathrm{Pb}$ are the major heavy metal contaminants in $\mathrm{El}$ Maleh Wadi and Mohammedia wetland surface water. The spatial variation of heavy metals concentrations shows that pollution discharged in El Maleh Wadi reaches Mohammedia wetland and may affect aquatic communities [22]. To prevent the ecosystem health risks, there is a critical need for implementing effective measures to reduce pollution in El Maleh Wadi, such as treatment of the old landfill leachate and treatment of domestic and industrial wastewater before discharging it into El Maleh wadi.

\section{References}

1. W. Duan, B. He, D. Nover, G. Yang, W. Chen, H. Meng, S. Zou, C. Liu. Water Quality Assessment and Pollution Source Identification of the Eastern Poyang Lake Basin Using Multivariate Statistical Methods, Sustainability 8, 133 (2016).

2. B.E.M. Keller, K. Lajtha, S. Cr.istofor. Trace metal concentrations in the sediments and plants of the Danube Delta, Romania, Wetlands 18, 42-50 (1998).

3. Y. B. Wang, C.W. Liu, P. Y. Liao, J.J. Lee. Spatial pattern assessment of river water quality: implications of reducing the number of monitoring stations and chemical parameters, Environ. Monit. Assess. 186, 1781-1792 (2014).

4. X. Jiang, S. Xu, Y. Liu, X.Wang. River ecosystem assessment and application in ecological restorations: A mathematical approach based on evaluatin gits structure and function, Ecol. Eng. 76, 151-157 (2015).

5. K. Pan, W.X. Wang. Trace metal contamination in estuarine and coastal environments in China, Sci. Total Environ. 421, 3-16 (2012).

6. K. Peters, M. Bundschuh, R. Schäfer. Review on the effects of toxicants on freshwater ecosystem functions, Environ. Pollut. 180, 324-329 (2013).

7. M. J. Kennish. Environmental threats and environmental future of estuaries, Environ. Conserv. 29 (01), 78-107 (2002).

8. M. Dakki, M.A. El Agbani. A. Qninba. Zones humides du Maroc inscrites jusqu'en 2005 sur la liste de la Convention Ramsar, Bull.Ins. Scien. Rabat, série générale 7, 226 (2011).

9. A. Serghini, A. El Abidi, S. El Blidi, M. Fekhaoui. Typologie spatio- temporelle et fonctionnement hydrologique du complexe des zones humides de Mohammedia (Maroc), Bulletin de l'Institut 
Scientifique, Rabat, Section Sciences de la Vie 35, 61-65. (2013)

10. A. Serghini. Diagnostic du complexe zones humides de Mohammedia : étude qualitative et quantitative des composantes physique (eau sédiment) et biologique de l'écosystème. Univ. Mohammed V, Rabat, Ph D, Thesis, 178 p (2003).

11. A. Serghini, M. Fekhaoui, A. El Abidi, S. El Blidi, R. Ben Akkame. Caractérisation hydrochimique d'un site Ramsar : le complexe de zones humides de Mohammedia (Maroc), Bull. Inst. Scien. Rabat, section Sciences de la Vie 32, 133-145 (2010).

12. Ministry of Energy, Mining, Water and Environment. Available online:

http://www.environnement.gov.ma/fr/lois-etreglementations/normes? $\mathrm{id}=1010$.

13. J. Rodier, L'analyse de l'eau, Eaux naturelles, Eaux résiduelles, Eaux de mer (Dunod, 2009).

14. K.C. Cheung, B.H.T. Poon, C.Y. Lan, M.H. Wong. Assessment of metal and nutrient concentrations in river water and sediment collected from the cities in the Pearl River Delta, South China, Chemosphere 52,1431-1440 (2003).

15. A. A. Elnazer, S. A. Salman, E. M. Seleem, E. M. Abu El Ella. Assessment of Some Heavy Metals Pollution and Bioavailability in Roadside Soil of Alexandria Marsa Matruh Highway, Egypt, Int. J. Ecol, 2015 (2015).

16. S. Souabi, K. Touzar, H. Chtioui, F. Khalil, K. Digua, M. Tahiri. Problématiques du chrome et du plomb dans les lixiviats des décharges publiques des villes de Mohameddia et de Fès, Déchets sciences et techniques 58, 37-44 (2010).

17. World Health Organization, Manganese and its compounds : environnemental aspects (Tech. rep. World Health Organization, 2004).

18. A.C. Bourg. Trace metal adsorption modelling and particle-water interactions in estuarine environments, Cont. Shelf Res.7, 1319-1332 (1987).

19. A. Turner, G. Millward, A. Bale, A. Morris, Application of the K D concept to the study of trace metal removal and desorption during estuarine mixing, Estuar. Coast. Shelf Sci. 36, 1-13 (1993).

20. M. Waeles, R.D. Riso, P. Le Corre. Seasonal variations of cadmium speciation in the Penzé estuary, NW France. Estuar. Coast. Shelf Sci. 65, 143-152 (2005).

21. Y.M. N'Guessan. Dynamique des éléments traces dans les eaux de surface des bassins versants agricoles de Gascogne, National Polytechnique Institute of Toulouse, Toulouse, Ph. D. Thesis, 253 p (2008).

22. R.B. Schäfer, M. Bundschuh, D.A. Rouch, E. Szöcs, P. C von der Ohe, V. Pettigrove, R. Schulz, D. Nugegoda, B.J. Kefford. Effects of pesticide toxicity, salinity and other environmental variables on selected ecosystem functions in streams and the relevance for ecosystem services, Sci. Total Environ. 415, 69-78 (2012). 